\title{
Economic Factors And Individual Investor Behavior: The Case Of The Greek Stock Exchange
}

Anna A. Merikas, (E-mail: merikas@otenet.gr), Deree College, Greece Andreas G. Merikas, (E-mail: merikas@otenet.gr), University of the Aegean, Greece George S. Vozikis, (E-mail: george-vozikis@utulsa.edu), University of Tulsa Dev Prasad, (E-mail: devprasad1@hotmail.com), University of Massachusetts, Lowell

\begin{abstract}
This study undertook an empirical survey of the factors, which mostly influence individual investor behavior in the Greek stock exchange. The results revealed by our sample of 150 respondents confirm that there seems to be a certain degree of correlation between the factors that behavioral finance theory and previous empirical evidence identify as the influencing factors for the average equity investor, and the individual behavior of active investors in the Athens Stock Exchange (ASE) influenced by the overall trends prevailing at the time of the survey in the ASE.
\end{abstract}

\subsection{Introduction}

Economic theory on investment decisions treats the investment decision of the individual as a macroeconomic aggregate and the microeconomic foundations of it are drawn from intertemporal utility theory. Individuals maximize their utility based on classic wealth criteria making a choice between consumption and investment through time.

However, some empirical studies that first appeared in the 1970s focused on the individual rather than aggregate investor profiles. At about the same time, the sub-discipline of behavioral finance evolved investigating investment choices under conditions of uncertainty. Research in behavioral finance produced three major theoretical streams, namely: Prospect Theory, Regret Aversion and Self Control. Each of these research streams captured and analyzed behavioral attributes of individual investors.

A Wharton survey contributed empirical data for the study of these research streams by examining how demographic variables influence the investment selection and portfolio composition process, and Blume and Friend (1978) provided a comprehensive study and overview of the Wharton survey results and its implications for behavioral finance. Furthermore, Cohn et al. (1975) provided tentative evidence that risk aversion decreases as the investor's wealth increases, while Riley and Chow showed that risk aversion decreases not only as wealth increases, but also as age, income and education increase. LeBaron, Farrelly and Gula (1992) added to the debate, by advocating that individuals' risk aversion is largely a function of visceral rather than rational considerations. On the other hand, Baker and Haslem (1974) contended that dividends, expected returns and the firm's financial stability are critical investment considerations for individual investors, and Baker, Haargrove and Haslem (1977) went a step further by proposing that investors behave rationally, taking into account the investment's risk/return tradeoff.

This study examined the factors that appear to exercise the greatest influence on the individual stock investor, and included not only the factors investigated by previous studies and derived from prevailing behavioral finance theories, but also introduced additional factors generated through personal interviews that have been found to influence the stockholders' investment decisions in Greece. To that effect, this paper will address two questions: First, what relative importance do decision variables and especially economic decision variables have for individual 
investors making stock purchase decisions? Secondly, are there homogeneous clusters or groups of variables that form identifiable decision determinants that investors rely upon when making stock investment decisions?

\subsection{Data And Methodology}

The names and addresses of 400 experienced shareholders were identified with the help of two major brokerage houses in Greece. Questionnaires were mailed to those individual investors and 150 full responses were received, for a 37.5 percent response rate. Participants were asked to evaluate the importance of 26 variables, identified from the literature and personal interviews as potentially influencing stock investment decisions, by marking only one of three choices for every one of the 26 variables: "Act On" for the variables which were important in making their investment decisions, "Some Influence" for the variables of secondary importance in their decision making, and "No Influence" for the variables that were not at all significant in their investment decision process.

The variables were ranked according to how frequently they were placed in each response category and factor analysis was used to examine how they interacted with each other. More specifically, factor analysis was used to identify the similarities among the variables and moreover, group them into identifiable categories.

\subsection{Results}

This study focused exclusively on the variables that were identified by the Greek investors to significantly affect their individual investor behavior, namely the "Act on" variables. The results and frequencies of the "Act on" variables are presented in Table 1. A more complete picture however, is shown in Table 2, which presents the same data sorted according to those factors that have the least impact and influence on investor behavior ("no influence").

Table 1. Frequency Distribution of Variables that Significantly Influence Investor Decisions

\begin{tabular}{|c|c|c|c|}
\hline Rank & Item & Frequency & Per Cent \\
\hline 1 & Expected corporate earnings & 108 & $72.0 \%$ \\
\hline 2 & Condition of financial statements & 87 & $58.0 \%$ \\
\hline 3 & Firm status in industry & 83 & $55.3 \%$ \\
\hline 4 & Reputation of the firm & 72 & $48.0 \%$ \\
\hline 5 & Feelings for a firm's products \& services & 71 & $47.3 \%$ \\
\hline 6 & Protection or not of the investor & 70 & $46.7 \%$ \\
\hline 7 & Expected dividends & 5 & $3.3 \%$ \\
\hline 8 & Recent price movements in a firm's stock & 60 & $40.0 \%$ \\
\hline 9 & "Get rich quick" & 56 & $37.3 \%$ \\
\hline 10 & Perceived ethics of firm & 56 & $37.3 \%$ \\
\hline 11 & Affordable share price & 54 & $36.0 \%$ \\
\hline 12 & Current economic indicators & 49 & $32.7 \%$ \\
\hline 13 & Opinions of the firm's majority stockholders & 48 & $32.0 \%$ \\
\hline 14 & Fluctuations/developments in the indices of the major markets & 48 & $32.0 \%$ \\
\hline 15 & Past performance of the firm's stock & 46 & $30.7 \%$ \\
\hline 16 & Gut feeling on economy & 46 & $30.7 \%$ \\
\hline 17 & Attractiveness of non-stock investments & 41 & $27.3 \%$ \\
\hline 18 & Diversification needs & 37 & $24.7 \%$ \\
\hline 19 & Brokerage house recommendation & 35 & $23.3 \%$ \\
\hline 20 & Coverage in the press & 30 & $20.0 \%$ \\
\hline 21 & Statements from politicians \& governmental officials & 28 & $18.7 \%$ \\
\hline 22 & Ease of obtaining borrowed funds & 28 & $18.7 \%$ \\
\hline 23 & Environmental record & 28 & $18.7 \%$ \\
\hline 24 & Family member opinions & 26 & $17.3 \%$ \\
\hline 25 & Friend or coworker recommendations & 24 & $16.0 \%$ \\
\hline 26 & Political party affiliation & 20 & $13.3 \%$ \\
\hline
\end{tabular}


The first conclusion drawn from the Table 1 is that most of the variables that were rated important are classic wealth maximization criteria such as "expected corporate earnings", "condition of financial statements", or "firm status in the industry". It was generally expected that these factors would be high on the list of criteria considered in choosing stock investments, especially given the fact that the survey was completed by experienced investors who survived even though they have been hit hard by the "bubble burst" of the Greek stock exchange that was initialized at the end of 1999. Secondly, apart from the wealth criteria, surprisingly more than half of the respondents considered no other factor important indicating that investors truly employ diverse decision criteria when choosing stocks. Third, it appears that despite the big blow to investors from the 1999 Greek stock market collapse, speculative factors like "get rich quick", "recent price movements in the firm's stocks", and "affordable share price" influenced significantly only $1 / 3$ of the respondents. Finally, environmental criteria like "coverage in the press", "statements from politicians and government officials", "ease of obtaining borrowed funds" and "political party affiliation" on which the pre-1999 bubble thrived on, were either totally unimportant to most experienced stock investors and only a very small percentage of them considers them significant investment decision criteria.

Table 2 ranks the variables by the frequency with which respondents ignore them when making stock purchases. As mentioned earlier, experienced investors rely mostly on wealth maximization criteria and they are self-reliant ignoring inputs of family members, politicians, and coworkers when purchasing stocks.

Table 2. Frequency Distribution of Variables that Least Influence Investor Decisions

\begin{tabular}{|c|c|c|c|}
\hline Rank & Item & Frequency & Per Cent \\
\hline 1 & Political party affiliation & 87 & $58.0 \%$ \\
\hline 2 & Statements from politicians \& governmental officials & 65 & $43.3 \%$ \\
\hline 3 & Friend or coworker recommendations & 56 & $37.3 \%$ \\
\hline 4 & Family member opinions & 49 & $32.7 \%$ \\
\hline 5 & Ease of obtaining borrowed funds & 37 & $24.7 \%$ \\
\hline 6 & Environmental record & 35 & $23.3 \%$ \\
\hline 7 & "Get rich quick" & 31 & $20.7 \%$ \\
\hline 8 & Past performance of the firm's stock & 27 & $18.0 \%$ \\
\hline 9 & Opinions of the firm's majority stockholders & 26 & $17.3 \%$ \\
\hline 10 & Brokerage house recommendation & 26 & $17.3 \%$ \\
\hline 11 & Perceived ethics of firm & 21 & $14.0 \%$ \\
\hline 12 & Coverage in the press & 21 & $14.0 \%$ \\
\hline 13 & Affordable share price & 19 & $12.7 \%$ \\
\hline 14 & Feelings for a firm's products \& services & 17 & $11.3 \%$ \\
\hline 15 & Fluctuations/developments in the indices of the major markets & 17 & $11.3 \%$ \\
\hline 16 & Attractiveness of non-stock investments & 12 & $8.0 \%$ \\
\hline 17 & Reputation of the firm & 11 & $7.3 \%$ \\
\hline 18 & Protection or not of the investor & 11 & $7.3 \%$ \\
\hline 19 & Recent price movements in firm's stock & 11 & $7.3 \%$ \\
\hline 20 & Current economic indicators & 10 & $6.7 \%$ \\
\hline 21 & Firm status in industry & 8 & $5.3 \%$ \\
\hline 22 & Expected dividends & 8 & $5.3 \%$ \\
\hline 23 & Gut feeling on economy & 8 & $5.3 \%$ \\
\hline 24 & Diversification needs & 8 & $5.3 \%$ \\
\hline 25 & Expected corporate earnings & 5 & $3.3 \%$ \\
\hline 26 & Condition of financial statements & 5 & $3.3 \%$ \\
\hline
\end{tabular}

Next, we analyzed the 26 variables using the varimax algorithm of orthogonal rotation, which is a very commonly used method of factor analysis. Evaluation of the resulting categories and rankings is highly subjective since factor analysis identifies only the homogeneous cluster groups. The "factor" categories displayed in Table 3 were found to be heavily loaded by a specific subset of the 26 variables in each particular case. The assignment of 
the factors was undertaken by the factor analysis. However, considerable subjective judgment and common sense was also employed to clarify discrepancies. Finally, the percentage frequencies of each set of variables were added together, and the resulting sum serves as a "weight of significance" attributed to each of the identified categories.

Table 3: Factors influencing the Equity Selection Process of Individual Investors

\begin{tabular}{|l|l|c|}
\hline LABEL & \multicolumn{1}{|c|}{ VARIABLES } & \% \\
\hline Accounting Information & Condition of financial statements & $58.0 \%$ \\
\hline $\mathbf{2 . 5 5}$ & Expected corporate earnings & $72.0 \%$ \\
\hline & Expected dividends & $3.3 \%$ \\
\hline & Firm status in industry & $55.3 \%$ \\
\hline & Affordable share price & $36.0 \%$ \\
\hline & Past performance of stock & $30.7 \%$ \\
\hline Subjective/Personal & Get rich quick & $37.3 \%$ \\
\hline $\mathbf{2 . 1 3}$ & Feelings for a firm's products \& services & $47.3 \%$ \\
\hline & Protection or not of the investor & $46.7 \%$ \\
\hline & Gut feeling on the economy & $30.7 \%$ \\
\hline & Perceived ethics of firm & $37.3 \%$ \\
\hline Neutral Information & Political party affiliation & $13.3 \%$ \\
\hline $\mathbf{2 . 1 0}$ & Coverage in the press & $20.0 \%$ \\
\hline & Recent price movements in a firm's stock & $40.0 \%$ \\
\hline & Statements from politicians \& governmental officials & $18.7 \%$ \\
\hline & Fluctuations/developments in the indices of the major markets & $32.0 \%$ \\
\hline & Current economic indicators & $32.7 \%$ \\
\hline & Reputation of the firm & $48.0 \%$ \\
\hline Advocate Recommendation & Environmental record & $18.7 \%$ \\
\hline $\mathbf{0 . 8 9}$ & Brokerage house recommendation & $23.3 \%$ \\
\hline & Family member opinions & $17.3 \%$ \\
\hline & Friend or coworker recommendations & $16.0 \%$ \\
\hline Personal Financial Needs & Opinions of the firm's majority stockholders & $32.0 \%$ \\
\hline $\mathbf{0 . 7 1}$ & Diversification needs & $24.7 \%$ \\
\hline & Attractiveness of non-stock investments & $27.3 \%$ \\
\hline & Ease of obtaining borrowed funds & $18.7 \%$ \\
\hline
\end{tabular}

First of all, it is safe to assume that the data obtained are indeed closely correlated with the individual behavior of active investors in the Athens Stock Exchange (ASE). The factor category displaying the highest significance is "Accounting Information" with a weight of 2.55. This was expected since, as mentioned earlier, the vast majority of the study's respondents were experienced stockholders. This result also indicates that experienced investors rely and emphasize rational decision making criteria, assigning a high value to this particular set of variables.

The next factor category with the highest loading was surprisingly, the criteria category of "Subjective/Personal" with a weight of 2.13. One can see clearly that the participant's responses reflect the overall euphoria that prevailed in the investor community in Greece, especially during the bull market period of pre-19992000. Particularly noteworthy and telling is the fact that 37.3 percent of the respondents considered their desire to "get rich quick" as an "Act on" influence factor. The factor category of "Neutral Information" received a weight of 2.10. Rationally speaking, the set of variables contained in this category are thought to constitute valuable information for a prospective investor. It is noteworthy that this category is ranked below the "Subjective/Personal" one, and this may be due to the lack of widespread knowledgeable information about a particular investment alternative, along with the resulting herd-behavior during the bull pre-1999 years, that contributed to the relative neglect of consideration of significant traditional variables. Finally, the last two categories of "Advocate Recommendation" and "Personal Financial Needs" received weights of 0.89 and 0.71 respectively. This fact shows that equity investors in the Athens Stock Exchange consider themselves quite independent of any influences outside 
their own personal feelings, although it is quite a mystery just how the investors' own subjective judgments were formed. Anyhow, the average investor fancies himself or herself free of any direct influence, and shows a perplexing total disregard for matters concerning their personal financial needs.

\subsection{Conclusion}

This study tested the tenets of the behavioral finance theory on the factors that influence investment choices under conditions of uncertainty. The analysis performed on the data collected appears to give a fairly accurate view of the average equity investor in the Athens Stock Exchange (ASE). Experienced and knowledgeable investors would readily admit that the structure and relative weights of the chosen categories reflect on the average, a still unsophisticated and immature investor profile. The results revealed by our sample of 150 respondents confirm that there seems to be a certain degree of correlation between the factors that behavioral finance theory and previous empirical evidence identify as the influencing factors for the average equity investor, and the individual behavior of active investors in the Athens Stock Exchange (ASE) influenced by the overall trends prevailing at the time of the survey in the ASE.

\subsection{Suggestions for Future Research}

This study examined the factors that appear to exercise the greatest influence on the individual stock investor, and included not only the factors investigated by previous studies and derived from prevailing behavioral finance theories, but also introduced additional factors generated through personal interviews that have been found to influence the stockholders' investment decisions in Greece. Future research should attempt to validate the two questions that this paper addressed: First, what relative importance do decision variables and especially economic decision variables have for individual investors making stock purchase decisions? Secondly, are there homogeneous clusters or groups of variables that form identifiable decision determinants that investors rely upon when making stock investment decisions? Cross national data collected from random samples of individual stock investors with substantial holdings should attempt to validate this study's conclusions that individuals base their stock purchase decisions on economic criteria combined with many other diverse variables, instead of merely relying on a single integrated approach.

\section{References}

1. Baker, H.K., and J.A. Haslem, "Toward the Development of Client-Specified Valuation Models," Journal of Finance, Vol. 29, No. 4, pp. 1255-1263, 1974.

2. Baker, H.K., M.B. Hargrove, and J.A. Haslem, "An Empirical Analysis of the Risk Return Preferences of Individual Investors," Journal of Financial and Quantitative Analysis, Vol. 12, No. 3, pp. 377-389, 1977.

3. $\quad$ Benningan, S., Financial Modeling, MIT Press, Cambridge, MA, 1997.

4. Blume, M.E., and I. Friend. "The Changing Role of the Individual Investor", John Wiley \& Sons, New York, New York, 1978.

5. Brock, W., J. Lakonishok, and B. LeBaron, "Simple Technical Trading Rules and the Stochastic Properties of Stock Returns," Journal of Finance, Vol. 47, No. 5, pp. 1731-64, 1992.

6. Chen, N.F., "Some Empirical Tests of the Theory of Arbitrage Pricing," Journal of Finance, Vol. 38, No. 5, pp. 1393-1414, 1983.

7. Cohn, R.A., W.G. Lewellen, R.C. Lease and G.G. Schlarbaum, "Individual Investor Risk Aversion and Investment Portfolio Composition,” Journal of Finance, Vol. 30, No. 2, pp. 605-620, 1975.

8. Goodwin, H.T., Active Portfolio Management. Richard D. Irwin, Chicago, Illinois, 1995.

9. Granger, G.W., "Investigating causal relationships by econometric methods and cross-spectral methods," Econometrica, Vol. 37, No. 3, pp. 424-38, 1969.

10. Grinold, R.C., "The Fundamental Law of Active Management," Journal of Portfolio Management, Vol. 15, No.3, pp. 30-37, 1989.

11. Grinold, R.C and R.N. Kahn, "Information Analysis: A Two-Step Approach to Information Ratios, Information Coefficients and the Value of Investment Information," Journal of Portfolio Management, Vol. 18, No. 3, pp. 14-21, 1992. 
12. LeBaron, D., G. Farrelly and S. Gula, "Facilitating a Dialogue on Risk: A Questionnaire Approach," Financial Analysts Journal, Vol. 45, No. 3, pp. 19-24, 1989.

13. Lewellen, W.G., R.C. Lease and G.C. Schlarbaum, "Patterns of Investment Strategy and Behaviour Among Individual Investors," Journal of Business, Vol. 50, No. 3, pp. 296-333, 1977.

14. Riley, W.B. and K.V.Chow, "Asset Allocation and Individual Risk Aversion," Financial Analysts Journal, Vol. 48, No. 6, pp. 32-37, 1992.

15. Thomas, R.L., Modern Econometrics. Addison-Wesley, Reading, Massachusetts, 1997.

16. Warren, W.E., R.E. Stevens and C.W. McConkey, "Using Demographic and Lifestyle Analysis to Segment Individual Investors," Financial Analysts Journal, Vol. 46, March/April, pp. 74-77, 1990.

Notes 